\section{The Importance of The Transport Sector In The Economy And Its Role}

Khidirov Kholmamat Juraevich

Termez State University, Uzbekistan

\section{G open ACCESS}

The American Journal Of Applied Sciences

JULY 2020

Page No.: 41-44

Volume-II Issue-VII

PUBLISHED: 30 JULY 2020

www.usajournalshub.com/inde x.php/tajas

Copyright: Original content from this work may be used under the terms of the Creative Commons Attribution 4.0 licence.

\title{
Abstract
}

This article discusses the fact that water and aviation services, which are the main types of transport networks, are also important for the national economy, which has had a significant positive impact on the socio-economic development of Surkhandarya.

Keywords: Oguz, Araks, Oks, Jayhun, Vakhsh, Vakhandaryo, Pamirdarya, Gunt, Bartangdarya, «Greek cross», Burdagoy

\section{Introduction}

In particular, water transport is a military-economic strategic area. This network served the national economy during the Russian occupation, the Soviet era and finally the years of independence. Historical analysis shows that in this direction a lot of important work has been done to ensure border security, preserve the ecological environment of the river, protect the flora and fauna associated with the river water and its banks, and more. In this regard, the Termez river port has a special place in the economic development of the 
Surkhandarya oasis.

The history of its formation has a history of 3500-4000 years. The reason for the existence of the port is, firstly, that this place is a convenient place to cross the river, and secondly, the closest road from the capital of Bactria, Bactria, through Termez to the capital of Sogdiana, Marakand.In ancient times, the Amudarya was called the river Oguz, Araks, Oks, Jayhun, Termez in historical sources. This river is considered one of the largest rivers not only in Central Asia, but also in the world. The Amudaryais called the Vakhandarya, starting from the northern slope of the Hindu Kush at an altitude of 4,000 meters and joining the Pamirs. The Pamirs, which flow from the Zarkol, are the second source of the Amudarya. The Pamirs, from the beginning to the end, flowed into the Vakhsh

The length of the Amudarya, including the headwaters, is 2,500 km. The Surkhandarya and Karasuv rivers are the last tributaries of the Amudarya, and for the next 1,400 km no other tributary joins it. The river flows through the Karakum and Kyzylkum deserts and flows into the Aral Sea.According to some sources, the Amudarya flowed into the Caspian Sea through the Uzbay River for 300 years, from the beginning of the 13th century to the 16th century. During the same period, the importance of Termez as a port increased. In ancient times, the most convenient river crossing in the Amu Darya was through the Prophet's Island near Termez.That is why VF Minorsky in his work "Greek Pass" said that "Yorgaq (Yordagoh) crossing existed in Termez even before it was founded by A.Makedonsky". Although we do not agree with VF Minorsky on who built the city of Termez and when, the opinion on the crossing is correct.

HafiziAbro also spoke about the crossing near the city of Termez. "Burdagoy is a place on the banks of the Ceyhan that connects to the Termez districts. Burdagoy is a Greek word meaning "hotel". The captains of the old ships were standing. "

This historian also thought about the crossing near the present Fayoztepa. It was natural that in such a convenient place of passage, among the necessities, there was a landing, a caravanserai, and later a village and a city. The Chinese ambassador, Di Zhang Qian, referred to the Amu Darya as Guy-Shui, referring to it as a navigable waterway that could carry merchants' goods over long distances. According to Polybius (201-120 BC), "the Ox (Amudarya) was a large ship, and at the expense of its tributaries, when it came to Bactria, it became very large."

This historian also thought about the crossing near the present Fayoztepa. It was natural that in such a convenient place of passage, among the necessities, there was a landing, a caravanserai, and later a village and a city. The Chinese ambassador, Di Zhang Qian, referred to the Amu Darya as Guy-Shui, referring to it as a navigable waterway that could carry merchants' goods over long distances. According to Polybius (201-120 BC), "the Ox 
(Amudarya) was a large ship, and at the expense of its tributaries, when it came to Bactria, it became very large."

The Termez river port is located in the southernmost part of Turan, at a relatively high point, close to the river crossing. Although the Amudarya turned from here, it did not wash its banks. Because Termez is built on a plateau of hard rocks. According to historian Arian Flavius (c. 95-175), a participant in the period of the Macedonian invasion, the width of the Oxus comes in six stages and is very deep, and the flow is turbulent and strong. Therefore, the army lost many of its horses before it passed through. The Amudarya was also widely used as a waterway during the Arab conquest. For example, according to Tabari (Abu Ja'far Muhammad ibnJarir at Tabari (839-923), Qutayba was a Shuman above Chaghaniyanand on his return from his voyage to Aharun, he boarded a boat on the Amudarya and went as far as Charjo. Craftsmen from Termez also built large royal ships. The kings and sultans who came to Termez on these ships sailed on the river. According to the full name of Abu Ishah Ibrahim ibn Muhammad al-Farsi al-Istahri (850-934), a fulltime tourist and geographer who lived in the first quarter of the tenth century in Istahri (second half of the ninth century), shipbuilders had a special place in the economic life of Termez. Most of the ships they built were sold abroad.Because during this period, the role and importance of Termez as a trading city increased. At that time, more than a dozen caravanserais were built in Termez. According to AbulfazlBayhaqi (full name of the great historian of the X1 century Abulfazl Muhammad ibn al-Husayn al-Kotib al-Bahaqi), the Ghaznavid sultan came to Mas'udTermez on a royal ship by river to hunt. According to Mahsidi, many ships were built in Termez at that time.

In 1717, an expedition led by Prince Bekovich-Cherkassky traveled from Astrakhan to Khiva under the direction of Peter 1 , who sought to perfect economic and trade relations between the peoples of Central Asia and the Russian state.

He also had to study the waterway of the Amudarya flowing to the Aral Sea. However, as a result of the destruction of the Bekovich-Cherkassky expedition by Khiva khan Shergozikhan, this instruction of Peter 1 was not carried out. After the Russian conquest of Central Asia in the second half of the 19th century, on April 27, 1873, the chief of the flotilla, led by Captain Sitnikov, entered the Amu Darya with 3 barges (cargo ships) in 2 steamships and sailed to Kungrad along the Ulkun River. depending on. However, since the deltas of the Amudaryahave not been explored, the expedition cannot move forward.

On August 1, 1873, Colonel-General N.V. Kaulbars inspected the confluence of the Amudarya, searched for the exits of the non-navigable road to the Aral Sea, and determined that the Amudaryacould be reached by the confluence of the Kuvan-Jarma, Lake Daukara, and the Yalisuv River. In this way, cargo began to be transported continuously from the Kozalinsk (fleet base on the Syrdarya) across the Aral Sea in the Amudarya. Later, on the banks of the Amudarya, the Kabakli Fortress and a defense structure were built and put into operation. 


\section{References}

1.Tursunov S.N and others, in the mirror of history of Surkhandarya.- Tashkent: "Sharq", 2001.- P.27.

2. MDA of the Republic of Uzbekistan, fund 303, list 2, case 161, page 14.

3. Denau branch of the state archive of Surkhandarya region, fund 425, list 1, case 99 , page 72.

4.B.Ahmedov. Sources from the history of Uzbekistan. - Tashkent: "Teacher". 1991 B.56.

5.Surkhandarya regional state archive, 95-Fund, 12-list, 56-work, 113-page.

6.Tursunov S.N. and others. History of Surkhandarya. -Tashkent: "East". 2004. -P.55.

7.Ahmedov B. Sources from the history of Uzbekistan. -Tashkent: Teacher. 1991. - B.80.

8. "SurkhanTongi" newspaper. 1997. 4 February. 11 (16092)

9. Surkhandarya regional state archive, fund 316, list 1 , case 126 , page 56.

10.Tursunov S.N. and others. History of Surkhandarya. -Tashkent: "East". 2004.- P.56. 